\title{
Role of leptin resistance in the development of obesity in older patients
}

This article was published in the following Dove Press journal:

Clinical Interventions in Aging

3 July 2013

Number of times this article has been viewed

\author{
Sophie Carter ${ }^{1, *}$ \\ Alexandre Caron ${ }^{2, *}$ \\ Denis Richard ${ }^{2}$ \\ Frédéric Picard' \\ 'Faculty of Pharmacy, ${ }^{2}$ Faculty \\ of Medicine, Dept Anatomy and \\ Physiology, Université Laval, Québec, \\ QC, Canada \\ *These authors contributed equally \\ to the work
}

Correspondence: Frédéric Picard Institut universitaire de cardiologie et de pneumologie de Québec, Y3I06 Pavillon Marguerite-d'Youville, 2725 Chemin Ste-Foy, Québec, QC GIV 4G5, Canada $\mathrm{Tel}+|4| 865687 \mid$ I ext 3737

Fax + I $4 \mid 86564942$

Email frederic.picard@criucpq.ulaval.ca

\begin{abstract}
Obesity is a global epidemic associated with aging-like cellular processes; in both aging and obesity, resistance to hormones such as insulin and leptin can be observed. Leptin is a circulating hormone/cytokine with central and peripheral effects that is released mainly by subcutaneous white adipose tissue. Centrally, leptin controls food intake, energy expenditure, and fat distribution, whereas it controls (among several others) insulin sensitivity, free fatty acids (FFAs) oxidation, and lipolysis in the periphery. Aging is associated with important changes in both the distribution and the composition of adipose tissue. Fat is redistributed from the subcutaneous to the visceral depot and increased inflammation participates in adipocyte dysfunction. This redistribution of adipose tissue in favor of visceral fat influences negatively both longevity and healthy aging as shown in numerous animal models. These modifications observed during aging are also associated with leptin resistance. This resistance blunts normal central and peripheral functions of leptin, which leads to a decrease in neuroendocrine function and insulin sensitivity, an imbalance in energy regulation, and disturbances in lipid metabolism. Here, we review how age-related leptin resistance triggers metabolic disturbances and affects the longevity of obese patients. Furthermore, we discuss the potential impacts of leptin resistance on the decline of brown adipose tissue thermogenesis observed in elderly individuals.
\end{abstract}

Keywords: leptin, obesity, aging, insulin sensitivity, brown adipose tissue

\section{Introduction}

Obesity is a worldwide socioeconomic concern. In 2013, the World Health Organization estimated that more than 1.4 billion adults are overweight and that more than 500 million are obese. ${ }^{1}$ This poses major economic and public health issues as some of the leading causes of mortality (ie, cardiovascular diseases and cancer) are strongly associated with obesity. ${ }^{2}$ Obesity also leads to a reduced lifespan and accelerates cellular processes similar to aging such as oxidative stress and disturbance in homeostatic pathways. $^{3-5}$ One important feature of obesity and aging in relation to morbidity and mortality is the dysregulation of both white adipose tissue (WAT) and brown adipose tissue (BAT) ${ }^{6,7}$ Adipose tissue has the capacity to secrete a large number of bioactive substances named adipokines. ${ }^{8}$ These adipokines, such as leptin, adiponectin, tumor necrosis factor alpha (TNF $\alpha$ ) and interleukin 6 (IL-6) have paracrine and/or endocrine functions and their dysregulation is a common ground for the development of insulin resistance, hypertension, and dyslipidemia. ${ }^{9}$ Another important common feature of obesity and aging is the development of resistance to certain hormones such as insulin and leptin, which triggers metabolic dysregulations such as type 2 diabetes and failure to regulate food intake as well as fat distribution. ${ }^{10}$ Since obese patients will make up 
an important proportion of the elderly population in the near future, it is important to determine the causes and effects of leptin resistance in age-related diseases.

\section{Physiological role of leptin}

Leptin, from the Greek "leptos" (thin), is a 16-kDa circulating protein with hormone/cytokine activities released by WAT, mainly subcutaneous fat. ${ }^{11}$ However, other tissues such as ovaries, skeletal muscles, stomach, and BAT also secrete leptin. ${ }^{12}$ There is a clear sexual dimorphism; women have higher circulating levels of leptin than men. ${ }^{13}$ Although some studies have postulated that these increased circulating levels of leptin in women were associated with their higher percentage of body fat when compared to men, others have demonstrated that higher leptin levels in women were independent of fat mass. ${ }^{14}$ These sex differences may be associated with a stimulating role of estrogen or a suppressing role of androgens on leptin production. ${ }^{15,16}$ Leptin circulates in the plasma as a free adipokine or bound to leptin-binding proteins, mainly its soluble receptor. In lean individuals, the great majority of leptin circulates in the bound form whereas it circulates in the free form in obese individuals. ${ }^{17,18}$ Physiologically, leptin is involved in regulating energy balance through central actions, which is of importance particularly in a context of fat accumulation and metabolic disorders. Leptin also has many peripheral actions, mainly on the circulatory and respiratory systems, glucose homeostasis, and reproduction (Table 1). ${ }^{12}$

Leptin is a key regulator of energy balance ${ }^{19,20}$ as it acts in the brain to decrease food intake and increase energy expenditure (Figure 1). ${ }^{21-23}$ The actions of leptin in neurons are mediated by the long isoform of the leptin receptor (LEPR-B), a splicing variant member of the class I cytokine receptor family. ${ }^{24}$ This variant is characterized by a long cytoplasmic region ${ }^{25}$ allowing the activation of the Jak-Stat signal transduction pathway, which is crucial for leptin action. ${ }^{24}$ LEPR-B is predominantly located in hypothalamic nuclei known to be involved in the regulation of energy balance, including the arcuate nucleus (ARC). ${ }^{26-29}$ LEPR-B is expressed in at least two distinct neuronal populations of the ARC. One population cosynthesizes the orexigenic (appetite-stimulating) neuropeptide Y (NPY) and agouti-related peptide (AgRP), and the other synthesizes pro-opiomelanocortin (POMC). ${ }^{30-32}$ In addition to being an orexigenic peptide, NPY suppresses the central leptinmediated growth and reproductive axes. ${ }^{33}$ In turn, POMC is processed to produce $\alpha$-melanocyte-stimulating hormone

Table I Summary of the main central and peripheral actions of leptin

\begin{tabular}{|c|c|c|}
\hline Site of action & Specific effects & References \\
\hline \multirow[t]{3}{*}{ Immunity } & Chemoattractant for macrophages & 59 \\
\hline & Induce the production of proinflammatory mediators by macrophages and T-lymphocytes & \\
\hline & Proliferation and differentiation of hemopoietic precursors & \\
\hline \multirow[t]{5}{*}{ Circulatory system } & Platelet aggregation & $60-65$ \\
\hline & Angiogenesis & \\
\hline & Wound repair & \\
\hline & Increase blood pressure & \\
\hline & Increase heart rate & \\
\hline \multirow[t]{2}{*}{ Lungs } & Lung capacity and compliance & $66-68$ \\
\hline & Predictor of lung function & \\
\hline \multirow[t]{2}{*}{ Skeletal muscle } & Triggers $\beta$-oxidation & 69,70 \\
\hline & Attenuates insulin-mediated lipogenic effects & \\
\hline \multirow[t]{4}{*}{ Liver } & Inhibits insulin binding & $71-75$ \\
\hline & Inhibits glucagon-activated cAMP production & \\
\hline & Profibrotic effect in hepatic stellar cells & \\
\hline & Increase the sensitivity to hepatic inflammation & \\
\hline \multirow[t]{4}{*}{ WAT } & Inhibits insulin binding & $77-82$ \\
\hline & Inhibits insulin-mediated effects on glucose transport, glycogen synthase activity and lipogenesis & \\
\hline & Stimulates lipolysis & \\
\hline & Pro-inflammatory cytokine & \\
\hline BAT & Increases the insulin-stimulated utilization of glucose & 47,89 \\
\hline \multirow[t]{2}{*}{ Reproduction } & Inhibits insulin-induced estradiol production & 91,92 \\
\hline & Follicular growth and maturation & \\
\hline \multirow[t]{5}{*}{ Brain } & Neuroendocrine/neuroprotective functions & $21-23,41,42,46,48,49$ \\
\hline & Decreases food intake & \\
\hline & Increases energy expenditure & \\
\hline & SNS activation & \\
\hline & Stimulates lipolysis & \\
\hline
\end{tabular}

Abbreviations: WAT, white adipose tissue; BAT, brown adipose tissue; cAMP, cyclic AMP; SNS, sympathetic nervous system. 

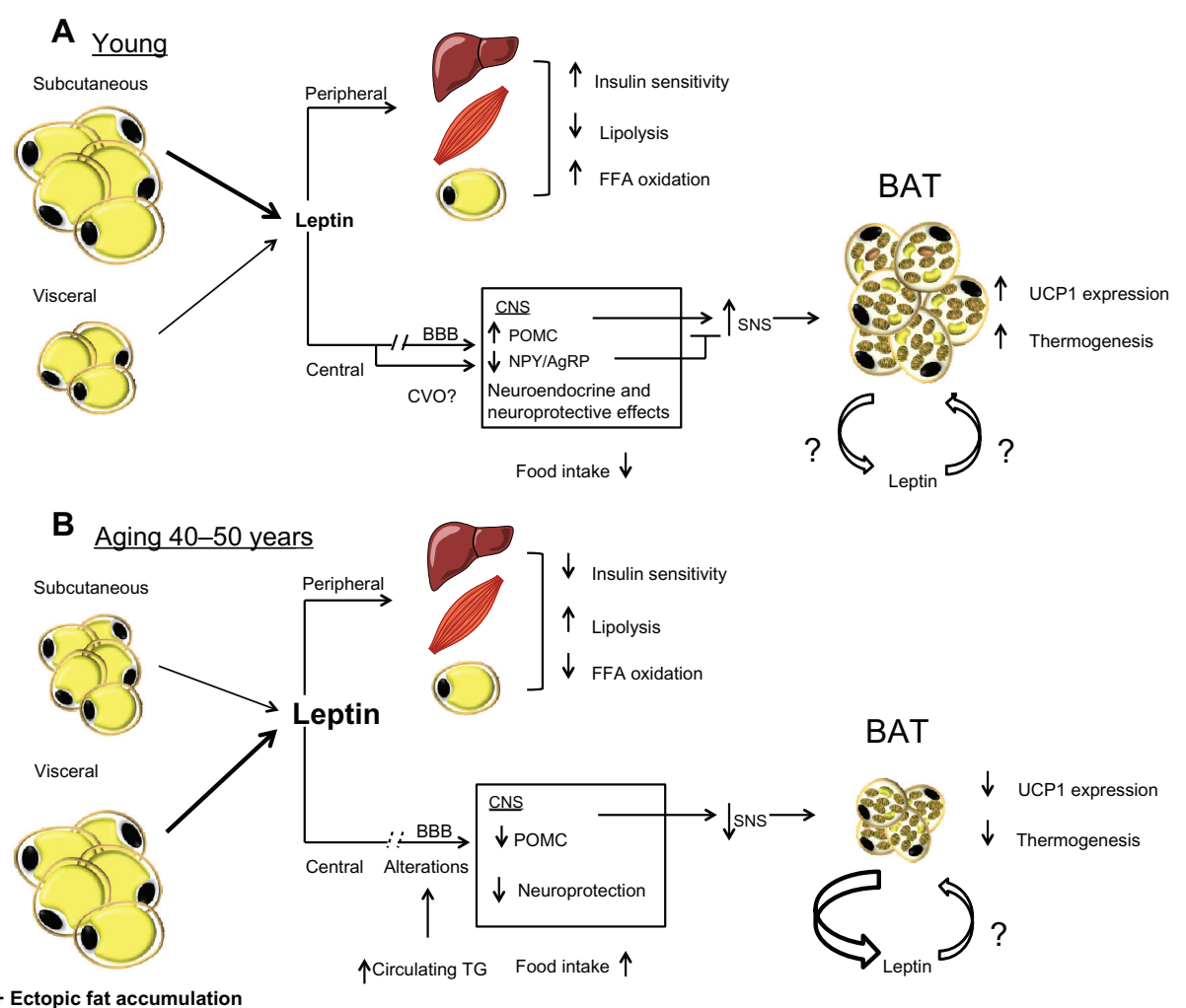

+ Ectopic fat accumulation

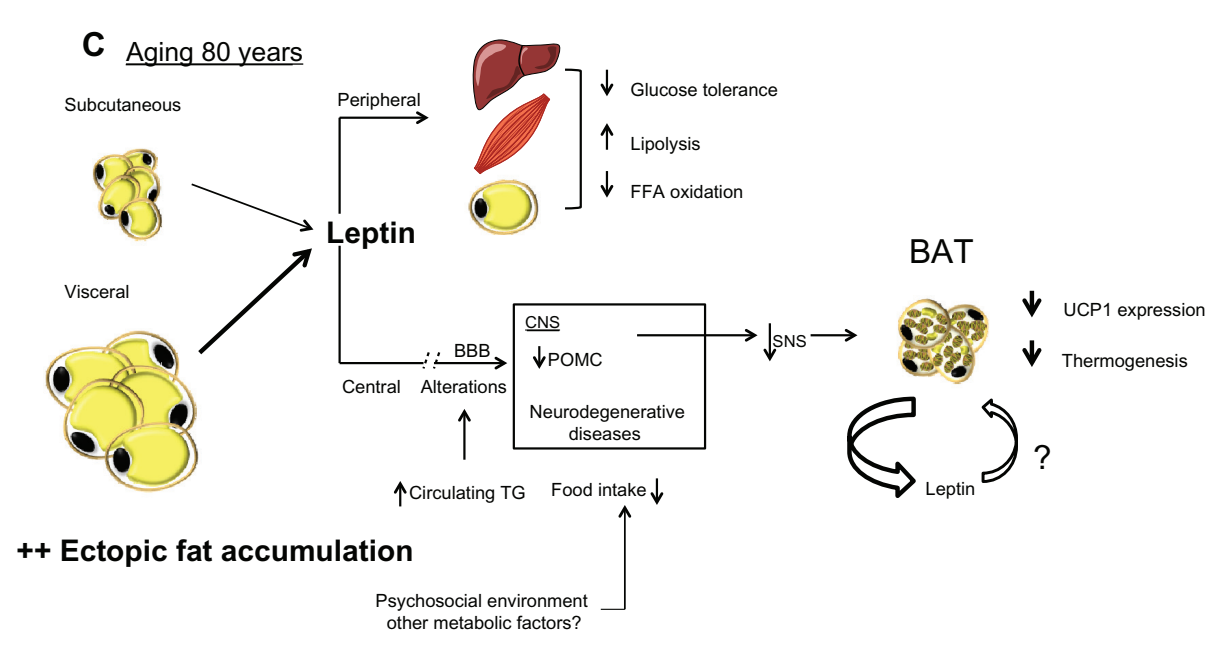

Figure I (A) Effects of leptin production in a young state. White adipocytes, mostly subcutaneous, secrete normal levels of leptin. Peripherally, leptin contributes to insulin sensitivity and free fatty acids oxidation in liver, muscle, and adipose tissue. Centrally, leptin reach its targets through its transport across the blood brain barrier provided by an active saturable transport system. Leptin is also transported through the circumventricular organs. Its binding to LEPRs expressed in the arcuate nucleus of the hypothalamus leads to an increase of POMC and a decrease of NPY/AgRP levels. This modulation of specific neuronal populations triggers SNS activation, which leads to an increase of UCPI transcription and thermogenesis in BAT. (B) Effects of leptin production in middle-age condition. Subcutaneous fat begins to be redistributed and white adipocytes, mostly visceral, produce a high amount of leptin. Peripherally, leptin resistance develops in the liver, muscle, and adipose tissue and causes a decrease in insulin sensitivity and FFAs oxidation and an increase in lipolysis. Centrally, alterations in the blood brain barrier decrease leptin transport to the CNS, which leads to a reduction in the production of POMC. This diminution blunts SNS signaling and induces BAT atrophy and leads to a decrease in both UCPI levels and thermogenesis. This BAT atrophy also contributes to an increase in leptin secretion. (C) Effects of old age on leptin secretion. The subcutaneous depot is atrophied and fat accumulates viscerally and mostly in ectopic depots. High levels of leptin are secreted by visceral adipose tissue, concomitantly with an increase in glucose intolerance peripherally probably attributed to a loss of leptin signaling. Centrally, levels of POMC are still decreased, which leads to a more important atrophy of BAT and quiescent thermogenesis. Since BAT is inactive, levels of secreted leptin by this tissue are increased.

Abbreviations: BAT, brown adipose tissue; BBB, blood-brain barrier; FFA, free fatty acids; CNS, central nervous system; POMC, proopiomelanocortin; NPY/AgRP, neuropeptide Y/agouti-related peptide; UCPI, uncoupling protein I; SNS, sympathetic nervous system; TG, triglycerides; CVO, circumventricular organs.

( $\alpha \mathrm{MSH})$, which leads to hypophagia by primarily activating the melanocortin-4 receptor (MC4R). ${ }^{34,35} \mathrm{AgRP}$ is an antagonist of $\alpha \mathrm{MSH} / \mathrm{MC} 4 \mathrm{R}$ signaling as well as an inverse agonist of MC4R activity itself. ${ }^{36} \mathrm{NPY} / \mathrm{AgRP}$ neurons also release $\gamma$-aminobutyric acid (GABA) and thus, can also negatively modulate $\mathrm{POMC}$ by a direct GABAergic synaptic mechanism. ${ }^{37}$ Leptin modulates energy balance by promoting several neuronal responses involving inhibition of the 
expression and secretion of NPY ${ }^{28,38}$ and stimulation of POMC synthesis. ${ }^{39,40}$ Consequently, microinjection of leptin into the ARC inhibits food intake. ${ }^{41}$ The involvement of leptin in the control of energy balance goes beyond food intake since leptin is also involved in energy expenditure by promoting BAT thermogenesis. ${ }^{21}$ A recent study showed a critical role for LEPR-B in the ARC in mediating the sympathetic nervous system (SNS) response to leptin. ${ }^{42}$ The role of leptin-induced activation of SNS-mediated BAT thermogenesis will be discussed in a later section.

Until recently and as described above, strong evidence suggested that the actions of leptin on energy balance were only due to its binding to LEPRs on AgRP/NPY and POMC neurons. However, since mice lacking LEPRs on either or both POMC and AgRP neurons develop very mild obesity, ${ }^{43,44}$ there are likely other leptin-responding neurons that contribute importantly to leptin's effects on energy balance. It has been shown that the effects of leptin on food intake and energy expenditure are also mediated by GABAergic neurons, raising the possibility that modulation of GABAergic output is a key aspect of leptin actions. ${ }^{45}$ Moreover, leptin action on presynaptic GABAergic neurons decreases the inhibitory tone to postsynaptic POMC neurons, explaining in part the orexigenic and thermogenic POMC-dependent effects of leptin. ${ }^{45}$ LEPRs-expressing GABAergic neurons are located in the ARC, where a small fraction are AgRP neurons, as well as in other hypothalamic nuclei known to be involved in energy balance regulation. However, although the investigation of these new first-order leptin-responsive neurons undoubtedly represents research perspectives, current knowledge mainly revolves around ARC NPY/AgRP and POMC neurons, which will be the focus of the present review. In addition to its effect on energy balance, central leptin is also involved in regulating peripheral lipid and glucose metabolism. ${ }^{46}$ Indeed, it has been shown that intracerebroventricular administration of leptin significantly increases insulin sensitivity, glucose utilization, and glucose uptake in peripheral tissue including BAT. ${ }^{47}$ Leptin also has neuroendocrine/neuroprotective functions; LEPRs are highly expressed in brain areas involved in learning and memory and leptin levels are associated with lower risk of dementia. ${ }^{48,49}$

Initial knowledge with regards to leptin effects on energy balance derived from cross-circulation experiments called parabiosis in $o b / o b$ and $d b / d b$ mice, which showed that the ob gene was responsible for the generation of a circulating factor that regulates energy balance, and that the $\mathrm{db}$ gene encodes the receptor for this factor. ${ }^{50}$ These mice weight up to three times more than normal mice and show remarkably high levels of body fat, an obese phenotype now known to be attributed to a deficiency in leptin production or its receptor respectively. ${ }^{50,51}$ Although human leptin gene mutations are relatively rare, some cases result in morbid obesity. ${ }^{52}$ Administration of leptin either peripherally or centrally to $o b / o b$ mice greatly reduces food intake and body weight. ${ }^{53,54}$ Moreover, a morbidly obese child who was found to have a mutation in the leptin gene was successfully treated with recombinant human leptin. ${ }^{55}$ Therefore, in a context in which leptin is circulating at physiological levels, leptin-sensitive patients should have a normal body weight. Consequently, leptin acts as a feedback signal from body energy stores to the brain; circulating levels diminish during starvation, when fat depots are depleted to support the energy need of the organism, and increase during refeeding, when fat depots are replenished. ${ }^{56}$ However, although absence of leptin leads to obesity, an excess of this hormone does not lead to a phenotype of leanness as theoretically expected. Indeed, leptin levels are found to be increased in obese humans and in several genetic and environmentally induced forms of rodent obesity, ${ }^{57,58}$ a state now commonly called leptin resistance, similar to the insulin resistance found in type 2 diabetes.

LEPR is also expressed in hemopoietic cells and studies showed that leptin could be linked to the proliferation and differentiation of hemopoietic precursors such as granulocyte-macrophage. ${ }^{59}$ These effects of leptin have also been suggested to synergize with those of stem-cell factor (SCF) at least in primitive and progenitor cells. ${ }^{59}$ Other reports propose a role for leptin in platelet aggregation, angiogenesis, and wound repair. ${ }^{60-62}$ Moreover, SNS activation by leptin goes beyond BAT thermogenesis, since leptin administration can increase heart rate and blood pressure in a dose-dependent manner. ${ }^{63,64}$ Elevated plasma leptin levels increase blood pressure in mice and plasma leptin concentration positively correlates with the sympathetic renal activation in humans, thus contributing to the development of hypertension. ${ }^{65}$

Leptin is also implicated in respiratory control. The combination of leptin deficiency and profound weight gain in adult $o b / o b$ mice can produce marked changes in the mechanics of respiration. In $o b / o b$ mice, total lung capacity and lung compliance are 50\% less than those of their wild-type counterparts. ${ }^{66} \mathrm{Ob} / \mathrm{ob}$ mice develop a rapid breathing pattern when compared to age-matched wild-type mice and exhibit a depressed hypercapnic ventilatory response (HCVR). ${ }^{67}$ These effects of leptin on ventilation were shown to be independent of obesity. ${ }^{67}$ In humans, clinical studies provided some 
evidence supporting these animal data. For example, leptin is a predictor of lung function in various conditions, including asthma and heart failure and correlates negatively with lung volume in chronic obstructive pulmonary disease patients. ${ }^{68}$ However, the pathophysiological implications of leptin in the respiratory function in humans remain to be clarified. In rodent skeletal muscle, both leptin mRNA and leptin receptor have been identified. Leptin triggers skeletal muscle FFAs oxidation by selectively activating $5^{\prime}$-AMP-activated protein kinase and attenuates insulin-mediated lipogenic effects by $50 \%{ }^{69,70}$ Additional studies are needed to specify the role of leptin on immune cells development and angiogenesis considering that these two processes are implicated in the metabolic dysregulations associated with obesity. Importantly, the effects of the high circulating levels of leptin found in leptin resistant states on immune cells differentiation and the implications of this process on low-grade inflammation should be determined.

In the liver, leptin inhibits both insulin binding and glucagon-activated cAMP production. ${ }^{71-73}$ Additionally, leptin was shown to have a profibrotic effect in hepatic stellate cells. ${ }^{74}$ This profibrotic effect was also described in a mouse model of hepatic steatosis where leptin was associated with an increase of CD-14+ Kupffer cell content. ${ }^{75}$ However, in leptin-deficient lipodystrophic patients suffering from nonalcoholic fatty liver disease (NAFLD), administration of leptin improved their condition dramatically. ${ }^{76}$ Taken together, these data suggest that the positive effects of leptin on triglycerides oxidation in the liver may overcome the effects of stellate and immune cells activation in the context of NAFLD. Since ectopic lipid storage is an important feature of aging, further studies are needed to better describe the effects of leptin on NAFLD. One important basic issue will be to determine whether mouse models of NAFLD are representative of an ectopic lipid storage disease and if findings can be translated to humans.

In WAT, leptin inhibits insulin binding and insulin-mediated effects on glucose transport, glycogen synthase activity, and lipogenesis. ${ }^{77,78}$ These effects can be observed when treating isolated rat adipocytes with recombinant leptin as it affects insulin sensitivity and alters important metabolic effects of insulin. ${ }^{79}$ Leptin can stimulate lipolysis as well; these effects have been demonstrated both in vitro and in vivo in mouse models. ${ }^{80,81}$ In WAT, leptin also functions as a proinflammatory adipokine by acting as a chemoattractant for macrophage ${ }^{82}$ and by inducing the production of proinflammatory mediators from macrophages and T lymphocytes such as TNF $\alpha$ and IL-6. ${ }^{83}$ TNF $\alpha$ interferes with preadipocyte differentiation and causes lipolysis, decreases size, and reduces insulin responsiveness in adipocytes. ${ }^{84}$ Considering the similarity between some of their responses, differentiating between central and peripheral effect of leptin on adipose tissue can be difficult. Consistently, this subject is still a matter of debate. Some studies showed that leptin's actions on lipolysis and insulin sensitivity in WAT are not mediated by the central nervous system since leptin can act on denervated fat. ${ }^{85}$ Others have determined that leptin also regulates WAT via the central nervous system considering that intracerebroventricular leptin infusion leads to lipolysis in WAT, as shown by a decrease of stearoyl-coenzyme A-desaturase-1 expression and an increase in hormonesensitive lipase expression. ${ }^{86,87}$ At the whole-body level, leptin has a strong, positive influence on glycemia; this subject was recently thoroughly reviewed elsewhere. ${ }^{88}$ Interestingly, leptin actions on lowering glycemia were suggested to be partly mediated via insulin-like growth factor (IGF)-binding protein 2, an established modulator of the IGF-1 pathway. Leptin also exerts peripheral effects on BAT since peripheral, but not central, administration of leptin in rats increases the insulinstimulated utilization of glucose in BAT. ${ }^{89}$

Finally leptin plays an important role in reproduction. ${ }^{90}$ LEPR is expressed in both ovary and prostate and leptin can inhibit insulin-induced estradiol production by granulose cells from bovine follicles. ${ }^{91}$ Moreover, a significant increase of circulating leptin levels is observed during ovarian hyperstimulation, which suggests that leptin plays a role in follicular growth and maturation. ${ }^{92}$ These observations can also be translated to animal models since infertility is a phenotype observed in both male and female leptin-deficient $o b / o b$ mice. In this model, circulating reproductive hormones are decreased in females, but it is possible to restore fertility with repeated injections of human leptin. ${ }^{93,94}$ Further studies will be necessary to determine the exact role of leptin in male fertility and the role of androgens in the control of leptin expression.

\section{Aging and inflammation in adipose tissue}

Aging is associated with an important redistribution of fat among the different depots. Body weight usually increases until middle age (30-50 years old) and declines thereafter..$^{95}$ In contrast, total fat mass peaks in early and middle old age (40-70 years old), which results in an increased percentage of body fat (Figure 2). ${ }^{96}$ This increased percentage of body fat is the consequence of both the increase in fat mass and the loss of fat-free mass encountered in the elderly, mainly in skeletal muscle and bone. Aging-associated redistribution of adipose tissue from the subcutaneous depot to the visceral compartment and ectopic sites namely muscle, liver, and 


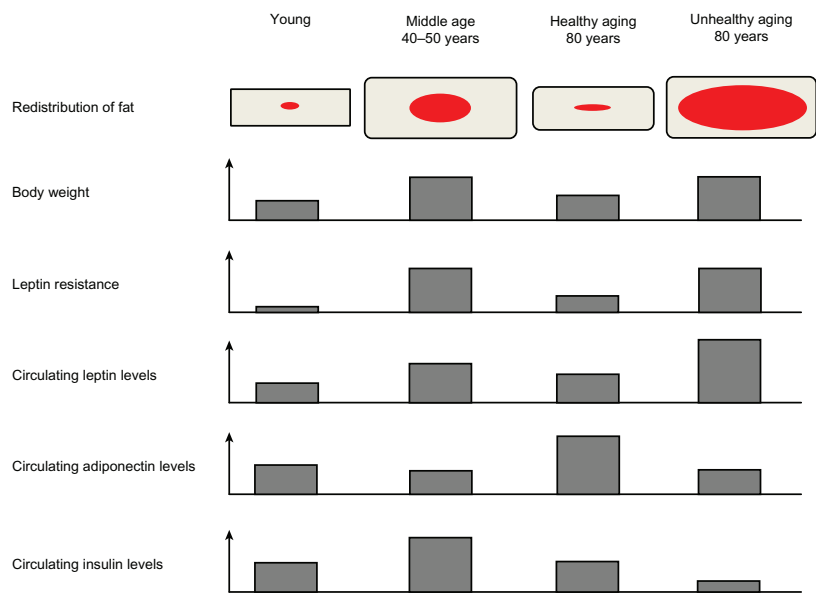

Figure 2 Representation of the different modifications regarding the redistribution of body fat, body weight, leptin resistance, and circulating levels of leptin, adiponectin, and insulin in conditions of youth, middle age, healthy aging, and unhealthy aging. Red and grey represent visceral and subcutaneous adipose tissue, respectively.

bone marrow has been shown to happen in subjects over 85 years old. ${ }^{97}$ This redistribution may potentially contribute to age-related dysfunction of these tissues ${ }^{98,99}$ but also has strong metabolic implications, since visceral adiposity and intramuscular lipid accumulation are markers of impaired glucose metabolism independently of adiposity. ${ }^{100}$ Aging is also associated with loss of BAT activity and brown preadipocyte dysfunction in rodents and humans. ${ }^{101-103}$ This process may contribute to energy imbalance since BAT is a thermoregulatory organ. Interestingly, leptin is also expressed in brown adipocytes. This expression seems to be only under conditions of inactivity and atrophy ${ }^{104}$ considering that cold and activation of $\beta_{3}$ adrenoreceptors both decrease leptin gene expression. ${ }^{105}$ Ueno et al showed that BAT thermogenic capacity and activity are diminished in both lean and obese old mice, but particularly in the obese ones. These observations suggest a synergy between aging and obesity in the context of leptin secretion and BAT thermogenesis. ${ }^{106}$

The different fat compartments undergo changes at different rates during aging (Table 2). ${ }^{107}$ Retro-orbital and peripheral subcutaneous adipose tissue tend to be lost first during aging whereas visceral fat tends to be preserved. ${ }^{108}$ Since subcutaneous adipose tissue is the principal source of leptin, ${ }^{109}$ its loss reduces leptin's capacity for $\beta$-oxidation of FFAs, which contributes to the increase of circulating FFAs upon aging. In turn, increased levels of circulating FFAs favor visceral and ectopic fat redistribution. ${ }^{110}$ Age-associated decline in fat depot size appears to be the result of a decrease in cell size as opposed to a decline in cell number. ${ }^{96}$ However, other reports have also noted a negative association between age and proliferation of subcutaneous preadipocytes, which may explain selective loss of subcutaneous adipose tissue with aging. ${ }^{111}$ Adipogenesis is likely to occur throughout the lifespan since adipocyte numbers remain constant or even increase in old age. ${ }^{107,112}$ However, during aging, preadipocytes experience a decrease in their potential to differentiate and replicate. ${ }^{113}$ Preadipocytes are precursor cells found in adipose tissue; they have the potential to differentiate, store triglycerides, respond to insulin, and secrete adipokines. ${ }^{107}$ In normal adipose tissue, fat mass is regulated by apoptosis and differentiation of preadipocytes. ${ }^{114}$ However, differentiation of preadipocytes isolated from aged rats and humans leads to a decrease of lipid accumulation and smaller fat cells when compared to preadipocytes from younger individuals. ${ }^{115,116}$ Since control for lipolysis is altered in fat cells upon aging, ${ }^{117,118}$ a decrease in lipid accumulation capacity could be a particularly important contributing factor for reduced adipocyte size. Thus, these age-related

Table 2 Modifications observed in different adipose tissue depot during aging

\begin{tabular}{|c|c|c|c|}
\hline Characteristics & Subcutaneous WAT & Visceral WAT & BAT \\
\hline Adipocyte size & $\begin{array}{l}\text { Young: - } \\
\text { Middle age: ++ } \\
\text { Old age: + }\end{array}$ & $\begin{array}{l}\text { Young: - } \\
\text { Middle age: ++ } \\
\text { Old age: }+\end{array}$ & $\begin{array}{l}\text { Young: }+ \\
\text { Middle age: }+ \text { /- } \\
\text { Old age: - }\end{array}$ \\
\hline Proportion of the depot & $\begin{array}{l}\text { Young: }+ \\
\text { Middle age: ++ } \\
\text { Old age: - }\end{array}$ & $\begin{array}{l}\text { Young: - } \\
\text { Middle age: + } \\
\text { Old age: ++ }\end{array}$ & $\begin{array}{l}\text { Young: ++ } \\
\text { Middle age: + } \\
\text { Old age: - }\end{array}$ \\
\hline Leptin secretion & $\begin{array}{l}\text { Young: }+ \\
\text { Middle age: }+ \text { to }++ \\
\text { Old age: }++\end{array}$ & $\begin{array}{l}\text { Young: +l- } \\
\text { Middle age: + } \\
\text { Old age: ++ }\end{array}$ & $\begin{array}{l}\text { Young: }-(?) \\
\text { Middle age: }+/-(?) \\
\text { Old age: }+(?)\end{array}$ \\
\hline $\begin{array}{l}\text { Relative contribution to } \\
\text { circulating leptin levels }\end{array}$ & $\begin{array}{l}\text { Young: ++ } \\
\text { Middle age: + } \\
\text { Old age: - }\end{array}$ & $\begin{array}{l}\text { Young: - } \\
\text { Middle age: + } \\
\text { Old age: ++ }\end{array}$ & $\begin{array}{l}\text { Young: - } \\
\text { Middle age: - } \\
\text { Old age: }+/-(?)\end{array}$ \\
\hline
\end{tabular}

Note: Question marks indicate that these subjects need to be further investigated. The minus signs represent a small size or amount whereas the plus signs indicate an important $(+)$ to very important $(++)$ size or amount.

Abbreviations: WAT, white adipose tissue; BAT, brown adipose tissue. 
intrinsic factors could affect fat mass by influencing both preadipocytes and adipocytes.

Changes in fat distribution associated with aging also lead to a modification of the secretion profile of adipokines. Circulating levels of inflammatory cytokines such as TNF $\alpha$, C-reactive protein, and IL-6 are elevated in both aging and obesity. ${ }^{119}$ High plasma leptin levels are observed in aging rodent models ${ }^{120,121}$ as well as in humans ${ }^{122,123}$ suggesting that aging is a leptin-resistant state. Although normal aging involves a decline in appetite, ${ }^{124}$ hyperleptinemia observed in the elderly may serve to counterbalance the decrease in hypothalamic responsiveness found in both animal and human models of aging. ${ }^{125}$ This decrease leads to a poor response to fasting and plays a causative role in the intolerance to catabolic situations. ${ }^{124}$ Increased fat mass may also contribute to elevated leptin in aging, but the increase is often disproportionate to the amount of fat. Consistently, leptin resistance during aging has been shown to be independent of fat mass in rats. ${ }^{126}$ Via its proinflammatory adipokine function, leptin also plays an important role in adipose tissue inflammation through preadipocytes activation. When preadipocytes are activated, they likely make a greater contribution to age-related adipose tissue dysfunction because of their number $\left(15 \%-50 \%\right.$ of cells in fat) ${ }^{127}$ They have full innate immune response capability, considering that they constitutively express toll-like receptor (TLR) 4 as adipocytes, but express TLR2 in a specific manner. This may contribute in part for the greater inflammatory responsiveness of preadipocytes compared to that of fat cells. ${ }^{128}$ Consistent with those findings, other reports suggest that cytokines and chemokines are expressed predominantly in preadipocytes rather than in adipocytes. ${ }^{128,129}$ Activated preadipocytes can even acquire a macrophage-like phenotype. ${ }^{130}$ This plasticity predisposes them to contribute to adipose tissue inflammation and dysfunction. ${ }^{130}$ Stressed preadipocytes may promote an inflammatory response leading to dysfunctionalities in adipose tissue as well as metabolic abnormalities.

The release of various cytokines and chemokines in adipose tissue attracts immune cells such as proinflammatory $\mathrm{T}$ lymphocytes and macrophages. Infiltration of visceral adipose tissue by macrophages is increased in both obese and lipodystrophic subjects. ${ }^{131,132}$ The macrophages also experience a shift of their activation: anti-inflammatory IL-10producing M2 macrophages are replaced by proinflammatory M1 macrophages. ${ }^{133}$ Macrophage infiltration is preceded by the infiltration of proinflammatory $\mathrm{T}$ lymphocytes and mast cells, and the decrease of anti-inflammatory $\mathrm{T}$ lymphocytes subtypes. This infiltration of immune cells also contributes to the production of proinflammatory cytokines, leading to a vicious circle. Although adipose tissue modifications caused by aging and obesity lead to highly similar metabolic abnormalities, the underlying mechanisms differ between the two conditions. ${ }^{134,135}$ Age-related metabolic dysfunctions cannot be explained completely by either the lipotoxicity associated with impaired lipid storage or by the increase in immune effectors. A combination of different mechanisms including, but not limited to, lipotoxicity caused by FFAs, inflammation and incapacity to store lipids may be responsible for the dysfunction of adipose tissue during aging.

\section{Association of leptin, insulin sensitivity, and longevity}

Adipokines from centenarians have been investigated and, in general, the subjects studied were lean (body mass index [BMI] of 19.4 \pm 3.3 ) and exhibited low levels of plasma leptin which was an indicator of their low adipose tissue mass. ${ }^{136}$ However, the lowest tertile of circulating leptin was surprisingly associated with higher all-cause mortality and, remarkably, these effects of low leptin levels on mortality were emphasized in patients with higher BMI. ${ }^{136}$ Thus, maintaining adipose tissue mass and function, mainly by keeping a functional leptin signaling, seems to be essential for normal physiological functions under energy-deprived conditions associated with aging. ${ }^{137}$ The role of leptin in sexual maturation makes associations between circulating leptin levels and longevity difficult since there is a positive correlation between age of reproduction and lifespan. ${ }^{138}$ In rodents, caloric restriction delays both sexual maturity and aging. ${ }^{139}$ Consistently, delayed sexual maturity and aging are observed in most animal models carrying a genetic mutation in the genes of the IGF1 pathway. ${ }^{140}$ These studies suggest that genes implicated in the regulation of sexual maturation include a subset of pleiotropic genes that mediate the trade-off between development and aging. ${ }^{141}$ The expression of other adipokines, like adiponectin, has also been associated with healthy aging and increased lifespan. Adiponectin, a hormone secreted exclusively by WAT, has circulating levels inversely associated with percent body fat in adults. ${ }^{142}$ Centenarians have higher plasma adiponectin concentration than BMI-matched younger adults. ${ }^{143}$ This hyperadiponectinemia in centenarians is also associated with a positive metabolic profile. ${ }^{143}$ Furthermore, two common variants of the adiponectin gene have been associated with higher adiponectin levels and longevity. ${ }^{143}$ Adiponectin levels were also inversely correlated with BMI, waist circumference, the percentage of body fat and with the homeostasis model assessment for insulin resistance, a marker of insulin resistance. ${ }^{143,144}$ 
In addition to adiponectin levels, insulin sensitivity has also been identified as an important component of longevity and healthy aging.

Several studies have been conducted on centenarians to better characterize the healthy aging phenotype. ${ }^{145,146}$ Numerous pathways have been identified and insulin sensitivity has been considered a key factor for healthy aging. ${ }^{147}$ In humans, insulin sensitivity decreases with advancing age and, accordingly, prevalence of type 2 diabetes increases with aging. ${ }^{148}$ When compared to elderly individuals over 75 years of age, centenarians have better preserved glucose tolerance and insulin sensitivity. ${ }^{149}$ Certain epidemiological evidence may provide a mechanistic insight into insulin sensitivity in centenarians: healthy centenarians with preserved insulin sensitivity have been shown to have a lower waist-to-hip ratio and a more favorable body fat content than their elderly controls. ${ }^{150}$ To test this hypothesis, numerous models have shown that improving insulin sensitivity leads to an increased longevity. Modifying adipose tissue either genetically, surgically or by caloric restriction has important effects on lifespan and age-associated diseases onset. Mice with fat-specific disruption of the insulin receptor gene (FIRKO mice) have decreased adiposity and lower fasting insulin levels, which lead to an extended lifespan. Concomitantly, FIRKO mice also have elevated serum adiponectin levels. ${ }^{151}$

Modification of adiposity is also possible without genetic modifications through caloric restriction. For more than 75 years, caloric restriction without malnutrition has been noted to prolong lifespan. ${ }^{152}$ This modification of caloric intake leads to an important loss of adipose tissue, especially visceral fat. ${ }^{153}$ The Barzilai group showed that surgical removal of visceral adipose tissue in rats increased lifespan and improved both insulin resistance and glucose intolerance. ${ }^{154,155}$ Comparatively, genetic interventions aimed at reducing fat mass are also associated with increased lifespan. For example, replacing the adipogenic transcription factor $\mathrm{CCAAT/}$ enhancer-binding protein $\alpha(\mathrm{C} / \mathrm{EBP} \alpha)$ with $\mathrm{C} / \mathrm{EBP} \beta$ in mice results in an increase in FFAs oxidation and reduced fat mass which leads to an extension of mean and maximal lifespan. ${ }^{156}$ These animal models reveal that lifespan is closely related to adiposity. Taken together, these data show that reduced adiposity combined with hyperadiponectinemia and insulin sensitivity constitutes an important conserved pathway implicated in prolonged lifespan (Figure 2). However, aging has often been associated with leptin and insulin resistance. These conditions have been linked to metabolic disorders and associated with age-related diseases, which increase morbidity and mortality.

\section{Leptin resistance and development of disease in old age}

The discovery of leptin has brought the long-awaited dream for a potential cure, which could induce satiety and weight loss in obese humans. This hope faded after the first observations of leptin resistance. ${ }^{157-159}$ Indeed, the magnitude of the weight loss achieved with leptin therapy in most obese individuals was modest compared to expectations, as most obese patients already exhibited elevated circulating levels of leptin as a consequence of their increased fat mass. ${ }^{56}$ Generally, leptin resistance is described as a reduced sensitivity with respect to the anorectic response to exogenously administrated leptin, ${ }^{160}$ but a universally accepted definition of this condition is currently under consideration by the National Institutes of Health. ${ }^{161}$ The identity of the underlying mechanisms of leptin resistance still remains unclear, but at least three possibilities have been postulated to underlie it: (1) a failure of circulating leptin to reach its targets in the brain; (2) a decrease in the expression of LEPR; and/or (3) an inhibition of the signaling events within selected neurons in specific brain regions. ${ }^{33,56,162,163}$ The former hypothesis in itself establishes a debate, as the mechanisms by which leptin achieves its targets in the brain are controversial. Leptin is transported across the blood-brain barrier (BBB) by an active saturable transport system, but some suggest an action also attributed to the BBB-exempted circumventricular organs. ${ }^{164,165}$ Decreased leptin transport across the BBB has been demonstrated in dietinduced obesity rodents ${ }^{166}$ and leptin resistance may be partly overcome by bypassing the BBB with intracerebroventricular injection of leptin. ${ }^{167}$ Moreover, cerebrospinal fluid levels of leptin are lower in obese individuals, in spite of high serum leptin levels, reinforcing the view of an impaired transport into the brain. ${ }^{168}$ Triglycerides have also been shown to mediate resistance to leptin by impairing the transport across the BBB. ${ }^{169}$ In addition to the contribution of a defective leptin transport, it is also suggested that a decreased number of LEPR-B, impaired signal transduction with old age, as well as a decrease in POMC with aging could also contribute to leptin resistance. ${ }^{170-172}$

Aged obese rats exhibit little or no anorectic or weight loss responses to peripherally infused leptin whereas young rats respond more robustly to leptin administration. ${ }^{121,172,173}$ Moreover, plasma leptin levels are high in aged animals and humans, thus suggesting that a failure in leptin action 
may represent one of the primary defects in the metabolic dysfunctions observed in aging. ${ }^{10,126}$ Failure of action of leptin with aging is also evidenced in the transgenic mouse model that overexpressed leptin since despite continuous secretion of leptin, aged mice showed an increase in body weight. ${ }^{174}$ Furthermore, a decreased number of LEPR-B has been demonstrated in the hypothalamic nuclei of old rats. ${ }^{170,172}$ Consistently, leptin injections failed to decrease body weight and hyperglycemia adequately in middle-aged obese and diabetic subjects. ${ }^{175,176}$ This suggests that leptin resistance also affects glycemic control. One other interesting way to determine the effects of leptin resistance during aging is to study the leptin receptor deficient $d b / d b$ mice longitudinally. In this model, young animals (5-6 weeks) are normoglycemic because their peripheral insulin resistance is overcome by an increase in insulin secretion. This hyperinsulinemia usually occurs for 2 to 3 months and is then followed by a rapid increase in glycemia, reflecting a defect in $\beta$-cells secretion. ${ }^{177}$ Aging in $d b / d b$ mice is also characterized by an important increase in plasma FFAs, ${ }^{178}$ higher mean arterial pressure, ${ }^{179}$ and lower hepatic insulin-binding capacity. ${ }^{180}$ Associated with the already well described important weight gain of $d b / d b$ mice, these metabolic factors contribute to the alteration of cardiac metabolism in favor of fatty acid oxidation and the progressive development of a cardiomyopathy. ${ }^{178}$ Whether these important age-related metabolic effects are directly mediated by leptin resistance or triggered by the consequent WAT accumulation still needs to be determined. Taken together, these data suggest that youth is associated with leptin sensitivity and that resistance to leptin occurs with aging. Aging is thus associated with failure in leptin's action, independent of obesity or changes in body fat distribution. ${ }^{126}$ The failure of leptin to regulate food intake, body fat and its distribution, and insulin action suggests that leptin resistance plays a major role in the metabolic syndrome that is typical to aging.

Leptin also regulates the excitability of inter alia hippocampal neurons as well as synaptic plasticity, ${ }^{49}$ demonstrating its involvement in neuroendocrine functions. Moreover, LEPR-B has been identified in neurons of the hippocampus, which are particularly vulnerable in Alzheimer disease $(\mathrm{AD}) .{ }^{181} \mathrm{AD}$ is a progressive neurodegenerative disease that involves a variety of symptoms such as progressive impairment of cognitive function, and impaired orientation and attention. ${ }^{182}$ Several reports from various clinical studies support the idea of a negative correlation between obesity and cognitive function, as well as a positive association between reduced levels of circulating leptin and risk for AD. ${ }^{182,183}$ Moreover, higher leptin levels are associated with lower risk of dementia and $\mathrm{AD}$ and less cognitive decline. ${ }^{184,185}$ Mice with targeted disruption of LEPR-B show a decreased synaptic plasticity associated with a poorer performance on spatial memory tasks, ${ }^{186}$ reinforcing the view that leptin has an undoubted neuroprotective implication. Since obesity worsens cognitive functions and leptin protects against neurodegeneration, higher prevalence of $\mathrm{AD}$ in obese elderly patients ${ }^{187}$ might be explained, in addition to low-grade inflammation and factors contributing to amyloidogenesis, by the presence of leptin resistance. Indeed, a large prospective study showed that aged individuals with the lowest leptin levels had a greater decline in their cognitive ability than those with the highest levels. ${ }^{185}$ Moreover, central obesity in midlife increases the risk of dementia later in life independently of comorbidities such as type 2 diabetes or cardiovascular diseases, indicating that leptin deficiency is commonly observed in $\mathrm{AD}$ and is someway associated with obesity characterized by leptin resistance ${ }^{183}$ Leptin also raises many research interests regarding its possible involvement in Parkinson's disease, epilepsy, and ischemia. ${ }^{181}$ All these lines of evidence suggest that leptin protects, at least indirectly, against age-related neuroendocrine/cognitive functions decline. ${ }^{182}$

\section{Leptin resistance and the loss of BAT activity upon aging}

BAT is a specialized fat depot with incredible thermogenic potential. ${ }^{188,189}$ It is found in relative abundance in small eutherian mammals, allowing them to live in cold environments without relying on the shivering process to produce heat. ${ }^{190}$ Brown adipocytes are characterized by multilocular lipid droplets and a high density of mitochondria, which contain uncoupling protein 1 (UCP1). UCP1 is located in the inner membrane of the mitochondria and uncouples substrate oxidation from adenosine triphosphate (ATP) synthesis, thereby providing the BAT capacity for nonshivering thermogenesis by dissipating energy as heat instead of generating ATP. ${ }^{188}$

Until recently, BAT was thought to disappear rapidly after birth in humans and play only a minimal physiological role in adults. ${ }^{191,192}$ However, recent evidence involving imaging procedures has brought a whole new perspective to the involvement of BAT in adults. ${ }^{193,194}$ In nuclear medicine, since fat and tumors capture the radioisotope ${ }^{18}$ fluorodeoxyglucose in the same way, brown fat has long eluded researchers. ${ }^{195}$ The use of combined positron emission tomography and computed tomography scanning has revealed the presence 
of a metabolically active fat depot in adult humans. ${ }^{195}$ BAT presence and activity are prevalent at a young age and remain present throughout adulthood, before declining robustly at an older age. ${ }^{196,197}$ Accordingly, BAT prevalence is higher in people younger than 50 years of age compared to patients older than 64 years. ${ }^{194}$ A prospective study also showed that adolescents exhibit a higher prevalence of BAT $(40 \%)$ compared to adults $(5 \%-10 \%) .{ }^{198}$ Thereby, all these lines of evidence suggest a protective role of BAT against age-related obesity. This age-related decline in BAT is thought to be the result of a gradual reduction of the amount of active BAT, followed by a reduction in the function and sensitivity at older age. ${ }^{199}$ Unfortunately, the exact timing of the age-related decline in BAT is still undetermined as well as the possible impact that age-related leptin resistance could exert on it. Different assumptions suggesting that age-related leptin resistance could affect the decline of BAT observed in elderly individuals are discussed below.

The age-associated decline in thermoregulation (Figure 1) ${ }^{195,200}$ has been related to BAT atrophy associated with a loss of UCP1 activity and has been shown to be influenced by sex, as females show a more important loss of thermogenic capacity with advancing age than males. ${ }^{200} \mathrm{In}$ this view, $o b / o b$ mice have lower metabolic rate and a lower body temperature than their lean counterparts and are unable to survive for more than a few hours when exposed to cold due to a failure in thermogenesis. ${ }^{201} \mathrm{BAT}$ of the $o b / o b$ mouse is usually thermogenically inactive, relatively atrophied, and has little UCP1, indicating that leptin deficiency leads to reduced BAT activity. ${ }^{106}$ Furthermore, BAT thermogenesis is triggered by the activation of the SNS, which abundantly innervates BAT. ${ }^{188,202}$ SNS nerve endings in BAT release noradrenaline, which activates $\beta$-adrenergic receptors and a downstream cascade of events leading to BAT cell proliferation, mitochondrial biogenesis, and increased expression and activation of UCP $1 .{ }^{188}$ In addition, BAT-mediated thermogenesis induced by noradrenaline is significantly decreased in old rats compared to their younger controls ${ }^{103}$ and impairment of brown adipocytes function with increasing age appears to be mediated, at least in part, by a disturbance in the intracellular adrenergic signaling. ${ }^{203,204}$ It is possible that a selective reduction in the SNS activity/sensitivity of BAT occurs with aging, even if paradoxically human SNS activity is generally increased in older individuals, at least in specific context such as at the cardiovascular level. ${ }^{205}$ The hypothesis of a selective reduction in SNS-BAT activity comes from the observations that selective neuronal circuits control SNS-mediated BAT thermogenesis in rodents. ${ }^{206}$
However, although it remains unclear whether such selectivity in SNS-BAT activity also exists in humans, it is known that leptin regulates SNS outflow to peripheral organs including BAT, suggesting that age-related leptin resistance could be related to this SNS-BAT activity reduction. ${ }^{207}$

In addition to stimulating food intake, NPY is known to suppress thermogenesis in BAT. ${ }^{208,209}$ Leptin increases energy expenditure through increasing thermogenesis in BAT and inhibits NPY, suggesting that age-related decrease in BAT activity could be the result of the inability of leptin to inhibit NPY-suppressed BAT thermogenesis. Moreover, aging is characterized by a significant decrease in POMC, ${ }^{171}$ which is activated by leptin and implicated in the activation of BAT thermogenesis mainly through $\alpha \mathrm{MSH} / \mathrm{MC} 4 \mathrm{R}$ signaling, suggesting another plausible mechanism that can attribute the decline of BAT activity to leptin resistance. Absence of MC4R has also been shown to compromise the ability of leptin to increase UCP1 expression in BAT. ${ }^{210}$ Several studies have demonstrated that changes in circulating levels of sex and thyroid hormones may contribute to age-related decline in BAT. ${ }^{211,212}$ Indeed, thyroid hormones have direct stimulatory effects on UCP-1 expression and enhance the adrenergic signaling to BAT. ${ }^{213}$ However, the possible involvement of age-related leptin resistance in thyroid receptor hormone-mediated BAT activity needs further studies. This avenue represents a promising future for a better comprehension of the effect of leptin resistance associated with age-induced reduction of BAT thermogenesis. Agerelated leptin resistance could selectively affect the SNS-BAT activity, as well as the NPY and/or POMC/ $\alpha$ MSH/MC4R modulation of BAT thermogenesis.

\section{Conclusion}

Leptin resistance and aging seem to be strongly intertwined. Both in the brain and in the periphery, the physiological actions of leptin experience a decrease during advancing age. The redistribution of adipose tissue and increased percent body fat observed during middle and old age contribute however to an increase in circulating leptin. This suggests that leptin resistance in aging is not overcome by an increase in leptin levels. Once established, leptin resistance increases adipose tissue inflammation through preadipocytes activation and seems to negatively impact cognitive function. When comparing the effects of leptin resistance to the metabolic dysfunctions observed in aging, leptin resistance appears to be an early contributor to the development of metabolic abnormalities in old age. Leptin resistance also exerts important functional impairment on 
BAT; this decrease in thermogenesis may act in synergy with the robust age-associated decline of BAT prevalence to contribute to the negative metabolic changes associated with unhealthy aging.

Studies on leptin show that this hormone is central to the dysregulations observed in aging and obesity. Whether leptin plays an important role in longevity is still to be determined, but since leptin resistance and aging share common metabolic alterations, its role in morbidity is very likely. Taking into account the important fat redistribution associated with aging, numerous questions are still unanswered considering leptin secretion and autocrine actions, particularly in BAT. Although it is now recognized that BAT remains present during adulthood, available data do not allow a causal relationship between BAT atrophy and increasing body weight with aging. A role for leptin resistance has not yet been defined in this weight-gain process. Preventing leptin resistance and/or counteracting the effects of aging on BAT decline represent a plausible therapeutic approach to prevent age-related metabolic alterations. To our knowledge, no drug is currently available for these applications. However, exercise could be a large-scale and affordable manner of maintaining leptin signaling and BAT functionality. Importantly, understanding the mechanisms underlying age-related leptin resistance and involved in modulating BAT activity is an unavoidable prerequisite before trying to treat metabolic disorders that life reserves.

\section{Acknowledgments}

Research related to the subject of this paper in F Picard laboratory was funded by grants from the Natural Sciences and Engineering Research Council of Canada and the Canadian Institutes of Health Research. F Picard holds a Senior Scholar Award from the Fond de recherche du QuébecSanté (FRQ-S). S Carter holds a FRQ-S PhD studentship. A Caron holds a Canadian Institutes of Health Research training program $\mathrm{PhD}$ studentship.

\section{Disclosure}

The authors declare no conflicts of interest in this work.

\section{References}

1. World Health Organization. Obesity and overweight fact sheet. 2012. Geneva, Switzerland. Retrieved from: http://www.who.int/mediacentre/ factsheets/fs311/en/.

2. Mokdad AH, Ford ES, Bowman BA, et al. Prevalence of obesity, diabetes, and obesity-related health risk factors, 2001. JAMA. 2003; 289(1):76-79.

3. Russell SJ, Kahn CR. Endocrine regulation of ageing. Nat Rev Mol Cell Biol. 2007;8(9):681-691.

4. Ahima RS. Connecting obesity, aging and diabetes. Nat Med. 2009; 15(9):996-997.
5. Peto R, Whitlock G, Jha P. Effects of obesity and smoking on US life expectancy. N Engl JMed. 2010;362(9):855-856; author reply, 856-857.

6. Miller RA. Aging and immune function. Int Rev Cytol. 1991;124: $187-215$.

7. Maury E, Brichard SM. Adipokine dysregulation, adipose tissue inflammation and metabolic syndrome. Mol Cell Endocrinol. 2010; 314(1):1-16.

8. Kershaw EE, Flier JS. Adipose tissue as an endocrine organ. J Clin Endocrinol Metab. 2004;89(6):2548-2556.

9. Scarpellini E, Tack J. Obesity and metabolic syndrome: an inflammatory condition. Dig Dis. 2012;30(2):148-153.

10. Ma XH, Muzumdar R, Yang XM, Gabriely I, Berger R, Barzilai N. Aging is associated with resistance to effects of leptin on fat distribution and insulin action. J Gerontol A Biol Sci Med Sci. 2002; 57(6):B225-B231.

11. Masuzaki H, Ogawa Y, Isse N, et al. Human obese gene expression. Adipocyte-specific expression and regional differences in the adipose tissue. Diabetes. 1995;44(7):855-858.

12. Margetic S, Gazzola C, Pegg GG, Hill RA. Leptin: a review of its peripheral actions and interactions. Int J Obes Relat Metab Disord. 2002;26(11):1407-1433.

13. Saad MF, Damani S, Gingerich RL, et al. Sexual dimorphism in plasma leptin concentration. J Clin Endocrinol Metab. 1997;82(2): 579-584.

14. Hassink SG, Sheslow DV, de Lancey E, Opentanova I, Considine RV, Caro JF. Serum leptin in children with obesity: relationship to gender and development. Pediatrics. 1996;98(2 Pt 1):201-203.

15. Hube F, Lietz U, Igel M, et al. Difference in leptin mRNA levels between omental and subcutaneous abdominal adipose tissue from obese humans. Horm Metab Res. 1996;28(12):690-693.

16. Rosenbaum M, Nicolson M, Hirsch J, et al. Effects of gender, body composition, and menopause on plasma concentrations of leptin. J Clin Endocrinol Metab. 1996;81(9):3424-3427.

17. Sinha MK, Opentanova I, Ohannesian JP, et al. Evidence of free and bound leptin in human circulation. Studies in lean and obese subjects and during short-term fasting. J Clin Invest. 1996;98(6): 1277-1282.

18. Brabant G, Nave H, Mayr B, Behrend M, van Harmelen V, Arner P. Secretion of free and protein-bound leptin from subcutaneous adipose tissue of lean and obese women. J Clin Endocrinol Metab. 2002;87(8): 3966-3970.

19. Halaas JL, Gajiwala KS, Maffei M, et al. Weight-reducing effects of the plasma protein encoded by the obese gene. Science. 1995; 269(5223):543-546.

20. Zhang G, Taneja KL, Singer RH, Green MR. Localization of pre-mRNA splicing in mammalian nuclei. Nature. 1994;372(6508):809-812.

21. Elmquist JK, Maratos-Flier E, Saper CB, Flier JS. Unraveling the central nervous system pathways underlying responses to leptin. Nat Neurosci. 1998;1(6):445-450.

22. Kalra SP, Dube MG, Pu S, Xu B, Horvath TL, Kalra PS. Interacting appetite-regulating pathways in the hypothalamic regulation of body weight. Endocr Rev. 1999;20(1):68-100.

23. Zhang Y, Scarpace PJ. Circumventing central leptin resistance: lessons from central leptin and POMC gene delivery. Peptides. 2006;27(2): 350-364.

24. Tartaglia LA. The leptin receptor. J Biol Chem. 1997;272(10): 6093-6096.

25. Friedman JM, Halaas JL. Leptin and the regulation of body weight in mammals. Nature. 1998;395(6704):763-770.

26. Fei H, Okano HJ, Li C, et al. Anatomic localization of alternatively spliced leptin receptors (Ob-R) in mouse brain and other tissues. Proc Natl Acad Sci U S A. 1997;94(13):7001-7005.

27. Mercer JG, Hoggard N, Williams LM, Lawrence CB, Hannah LT, Trayhurn P. Localization of leptin receptor mRNA and the long form splice variant $(\mathrm{Ob}-\mathrm{Rb})$ in mouse hypothalamus and adjacent brain regions by in situ hybridization. FEBS Lett. 1996;387(2-3): 113-116. 
28. Schwartz MW, Seeley RJ, Campfield LA, Burn P, Baskin DG. Identification of targets of leptin action in rat hypothalamus. $J$ Clin Invest. 1996;98(5):1101-1106.

29. Elmquist JK, Bjorbaek C, Ahima RS, Flier JS, Saper CB. Distributions of leptin receptor mRNA isoforms in the rat brain. J Comp Neurol. 1998;395(4):535-547.

30. Elmquist JK, Elias CF, Saper CB. From lesions to leptin: hypothalamic control of food intake and body weight. Neuron. 1999;22(2): 221-232.

31. Baskin DG, Breininger JF, Schwartz MW. Leptin receptor mRNA identifies a subpopulation of neuropeptide $Y$ neurons activated by fasting in rat hypothalamus. Diabetes. 1999;48(4):828-833.

32. Baskin DG, Schwartz MW, Seeley RJ, et al. Leptin receptor long-form splice-variant protein expression in neuron cell bodies of the brain and co-localization with neuropeptide Y mRNA in the arcuate nucleus. J Histochem Cytochem. 1999;47(3):353-362.

33. Myers MG, Cowley MA, Munzberg H. Mechanisms of leptin action and leptin resistance. Ann Rev Physiol. 2008;70:537-556.

34. Huszar D, Lynch CA, Fairchild-Huntress V, et al. Targeted disruption of the melanocortin-4 receptor results in obesity in mice. Cell. 1997;88(1): 131-141.

35. Butler AA, Cone RD. The melanocortin receptors: lessons from knockout models. Neuropeptides. 2002;36(2-3):77-84

36. Ollmann MM, Wilson BD, Yang YK, et al. Antagonism of central melanocortin receptors in vitro and in vivo by agouti-related protein. Science. 1997;278(5335):135-138.

37. Mercer AJ, Hentges ST, Meshul CK, Low MJ. Unraveling the central proopiomelanocortin neural circuits. Front Neurosci. 2013;7:19.

38. Stephens TW, Basinski M, Bristow PK, et al. The role of neuropeptide $\mathrm{Y}$ in the antiobesity action of the obese gene product. Nature. 1995; 377(6549):530-532.

39. Mizuno TM, Kleopoulos SP, Bergen HT, Roberts JL, Priest CA, Mobbs CV. Hypothalamic pro-opiomelanocortin mRNA is reduced by fasting and [corrected] in ob/ob and $\mathrm{db} / \mathrm{db}$ mice, but is stimulated by leptin. Diabetes. 1998;47(2):294-297.

40. Schwartz MW, Seeley RJ, Woods SC, et al. Leptin increases hypothalamic pro-opiomelanocortin mRNA expression in the rostral arcuate nucleus. Diabetes. 1997;46(12):2119-2123.

41. Satoh N, Ogawa Y, Katsuura G, et al. The arcuate nucleus as a primary site of satiety effect of leptin in rats. Neurosci Lett. 1997;224(3): $149-152$.

42. Harlan SM, Morgan DA, Agassandian K, et al. Ablation of the leptin receptor in the hypothalamic arcuate nucleus abrogates leptin-induced sympathetic activation. Circ Res. 2011;108(7):808-812.

43. Balthasar N, Coppari R, McMinn J, et al. Leptin receptor signaling in POMC neurons is required for normal body weight homeostasis. Neuron. 2004;42(6):983-991.

44. van de Wall E, Leshan $\mathrm{R}, \mathrm{Xu} \mathrm{AW}$, et al. Collective and individual functions of leptin receptor modulated neurons controlling metabolism and ingestion. Endocrinology. 2008;149(4):1773-1785.

45. Vong L, Ye C, Yang Z, Choi B, Chua S Jr, Lowell BB. Leptin action on GABAergic neurons prevents obesity and reduces inhibitory tone to POMC neurons. Neuron. 2011;71(1):142-154.

46. Nogueiras R, Wilson H, Rohner-Jeanrenaud F, Tschop MH. Central nervous system regulation of adipocyte metabolism. Regul Pept. 2008; 149(1-3):26-31.

47. Minokoshi Y, Haque MS, Shimazu T. Microinjection of leptin into the ventromedial hypothalamus increases glucose uptake in peripheral tissues in rats. Diabetes. 1999;48(2):287-291.

48. Marwarha G, Ghribi O. Leptin signaling and Alzheimer's disease. Am J Neurodegener Dis. 2012;1(3):245-265.

49. Oomura Y, Hori N, Shiraishi T, et al. Leptin facilitates learning and memory performance and enhances hippocampal CA1 long-term potentiation and CaMK II phosphorylation in rats. Peptides. 2006; 27(11):2738-2749.

50. Coleman DL. Obese and diabetes: two mutant genes causing diabetesobesity syndromes in mice. Diabetologia. 1978;14(3):141-148.
51. Zhang Y, Proenca R, Maffei M, Barone M, Leopold L, Friedman JM. Positional cloning of the mouse obese gene and its human homologue. Nature. 1994;372(6505):425-432.

52. Montague CT, Farooqi IS, Whitehead JP, et al. Congenital leptin deficiency is associated with severe early-onset obesity in humans. Nature. 1997;387(6636):903-908.

53. Pelleymounter MA, Cullen MJ, Baker MB, et al. Effects of the obese gene product on body weight regulation in ob/ob mice. Science. 1995; 269(5223):540-543.

54. Campfield LA, Smith FJ, Guisez Y, Devos R, Burn P. Recombinant mouse $\mathrm{OB}$ protein: evidence for a peripheral signal linking adiposity and central neural networks. Science. 1995;269(5223):546-549.

55. Farooqi IS, Jebb SA, Langmack G, et al. Effects of recombinant leptin therapy in a child with congenital leptin deficiency. $N$ Engl J Med. 1999;341(12):879-884.

56. Munzberg H, Bjornholm M, Bates SH, Myers MG Jr. Leptin receptor action and mechanisms of leptin resistance. Cell Mol Life Sci. 2005; 62(6):642-652.

57. Stunkard AJ, Harris JR, Pedersen NL, McClearn GE. The body-mass index of twins who have been reared apart. $N$ Engl J Med. 1990; 322(21):1483-1487.

58. Maffei M, Halaas J, Ravussin E, et al. Leptin levels in human and rodent: measurement of plasma leptin and ob RNA in obese and weight-reduced subjects. Nat Med. 1995;1(11):1155-1161.

59. Gainsford T, Alexander WS. A role for leptin in hemopoieses? Mol Biotechnol. 1999;11(2):149-158.

60. Nakata M, Yada T, Soejima N, Maruyama I. Leptin promotes aggregation of human platelets via the long form of its receptor. Diabetes. 1999;48(2):426-429.

61. Sierra-Honigmann MR, Nath AK, Murakami C, et al. Biological action of leptin as an angiogenic factor. Science. 1998;281(5383):1683-1686.

62. Ring BD, Scully S, Davis CR, et al. Systemically and topically administered leptin both accelerate wound healing in diabetic ob/ob mice. Endocrinology. 2000;141(1):446-449.

63. Haynes WG, Morgan DA, Walsh SA, Mark AL, Sivitz WI. Receptormediated regional sympathetic nerve activation by leptin. J Clin Invest. 1997; 100(2):270-278.

64. Shek EW, Brands MW, Hall JE. Chronic leptin infusion increases arterial pressure. Hypertension. 1998;31(1 Pt 2):409-414.

65. Shankar A, Xiao J. Positive relationship between plasma leptin level and hypertension. Hypertension. 2010;56(4):623-628.

66. Tankersley CG, O'Donnell C, Daood MJ, et al. Leptin attenuates respiratory complications associated with the obese phenotype. $J \mathrm{Appl}$ Physiol. 1998;85(6):2261-2269.

67. O'Donnell CP, Tankersley CG, Polotsky VP, Schwartz AR, Smith PL. Leptin, obesity, and respiratory function. Respir Physiol. 2000;119(2-3): 163-170.

68. Malli F, Papaioannou AI, Gourgoulianis KI, Daniil Z. The role of leptin in the respiratory system: an overview. Respir Res. 2010;11:152.

69. Minokoshi Y, Kim YB, Peroni OD, et al. Leptin stimulates fatty-acid oxidation by activating AMP-activated protein kinase. Nature. 2002; 415(6869):339-343.

70. Muoio DM, Dohm GL, Fiedorek FT Jr, Tapscott EB, Coleman RA. Leptin directly alters lipid partitioning in skeletal muscle. Diabetes. 1997;46(8):1360-1363.

71. Nowak KW, Mackowiak P, Nogowski L, Szkudelski T, Malendowicz LK. Acute leptin action on insulin blood level and liver insulin receptor in the rat. Life Sci. 1998;63(15):1347-1352.

72. Zhao AZ, Shinohara MM, Huang D, et al. Leptin induces insulin-like signaling that antagonizes cAMP elevation by glucagon in hepatocytes. J Biol Chem. 2000;275(15):11348-11354.

73. Abbatecola AM, Rizzo MR, Barbieri M, et al. Postprandial plasma glucose excursions and cognitive functioning in aged type 2 diabetics. Neurology. 2006;67(2):235-240.

74. Saxena NK, Ikeda K, Rockey DC, Friedman SL, Anania FA. Leptin in hepatic fibrosis: evidence for increased collagen production in stellate cells and lean littermates of ob/ob mice. Hepatology. 2002;35(4):762-771. 
75. Imajo K, Fujita K, Yoneda M, et al. Hyperresponsivity to low-dose endotoxin during progression to nonalcoholic steatohepatitis is regulated by leptin-mediated signaling. Cell Metab. 2012;16(1):44-54.

76. Javor ED, Ghany MG, Cochran EK, et al. Leptin reverses nonalcoholic steatohepatitis in patients with severe lipodystrophy. Hepatology. 2005;41(4):753-760.

77. Walder K, Filippis A, Clark S, Zimmet P, Collier GR. Leptin inhibits insulin binding in isolated rat adipocytes. J Endocrinol. 1997;155(3):R5-R7.

78. Zierath JR, Frevert EU, Ryder JW, Berggren PO, Kahn BB. Evidence against a direct effect of leptin on glucose transport in skeletal muscle and adipocytes. Diabetes. 1998;47(1):1-4.

79. Muller G, Ertl J, Gerl M, Preibisch G. Leptin impairs metabolic actions of insulin in isolated rat adipocytes. J Biol Chem. 1997;272(16): 10585-10593.

80. Fruhbeck G, Gomez-Ambrosi J. Modulation of the leptin-induced white adipose tissue lipolysis by nitric oxide. Cell Signal. 2001; 13(11):827-833

81. Fruhbeck G, Aguado M, Martinez JA. In vitro lipolytic effect of leptin on mouse adipocytes: evidence for a possible autocrine/paracrine role of leptin. Biochem Biophys Res Commun. 1997;240(3):590-594.

82. Santos-Alvarez J, Goberna R, Sanchez-Margalet V. Human leptin stimulates proliferation and activation of human circulating monocytes. Cell Immunol. 1999;194(1):6-11.

83. La Cava A, Matarese G. The weight of leptin in immunity. Nat Rev Immunol. 2004;4(5):371-379.

84. Hube F, Hauner H. The role of TNF-alpha in human adipose tissue: prevention of weight gain at the expense of insulin resistance? Horm Metab Res. 1999;31(12):626-631.

85. Wang ZW, Zhou YT, Lee Y, Higa M, Kalra SP, Unger RH. Hyperleptinemia depletes fat from denervated fat tissue. Biochem Biophys Res Commun. 1999;260(3):653-657.

86. Lin J, Choi YH, Hartzell DL, Li C, Della-Fera MA, Baile CA. CNS melanocortin and leptin effects on stearoyl-CoA desaturase-1 and resistin expression. Biochem Biophys Res Commu. 2003;311(2):324-328.

87. Tajima D, Masaki T, Hidaka S, Kakuma T, Sakata T, Yoshimatsu H. Acute central infusion of leptin modulates fatty acid mobilization by affecting lipolysis and mRNA expression for uncoupling proteins. Exp Biol Med (Maywood). 2005;230(3):200-206.

88. Coppari R, Bjorbaek C. Leptin revisited: its mechanism of action and potential for treating diabetes. Nat Rev Drug Discov. 2012;11(9): 692-708.

89. Siegrist-Kaiser CA, Pauli V, Juge-Aubry CE, et al. Direct effects of leptin on brown and white adipose tissue. J Clin Invest. 1997;100(11): 2858-2864.

90. Chehab FF, Mounzih K, Lu R, Lim ME. Early onset of reproductive function in normal female mice treated with leptin. Science. 1997; 275(5296):88-90.

91. Spicer LJ, Francisco CC. The adipose obese gene product, leptin: evidence of a direct inhibitory role in ovarian function. Endocrinology. 1997;138(8):3374-3379.

92. Lindheim SR, Sauer MV, Carmina E, Chang PL, Zimmerman R, Lobo RA. Circulating leptin levels during ovulation induction: relation to adiposity and ovarian morphology. Fertil Steril. 2000;73(3): 493-498.

93. Hoggard N, Hunter L, Trayhurn P, Williams LM, Mercer JG. Leptin and reproduction. Proc Nutr Soc. 1998;57(3):421-427.

94. Mounzih K, Lu R, Chehab FF. Leptin treatment rescues the sterility of genetically obese ob/ob males. Endocrinology. 1997;138(3): 1190-1193.

95. Baumgartner RN, Stauber PM, McHugh D, Koehler KM, Garry PJ. Cross-sectional age differences in body composition in persons 60+ years of age. J Gerontol A Biol Sci Med Sci. 1995;50(6): M307-M316.

96. Cartwright MJ, Tchkonia T, Kirkland JL. Aging in adipocytes: potential impact of inherent, depot-specific mechanisms. Exp Gerontol. 2007;42(6):463-471.
97. Kuk JL, Saunders TJ, Davidson LE, Ross R. Age-related changes in total and regional fat distribution. Ageing Res Rev. 2009;8(4):339-348.

98. Rosen CJ, Bouxsein ML. Mechanisms of disease: is osteoporosis the obesity of bone? Nat Clin Pract Rheumatol. 2006;2(1):35-43.

99. Unger RH. Longevity, lipotoxicity and leptin: the adipocyte defense against feasting and famine. Biochimie. 2005;87(1):57-64.

100. Goodpaster BH, Krishnaswami S, Resnick H, et al. Association between regional adipose tissue distribution and both type 2 diabetes and impaired glucose tolerance in elderly men and women. Diabetes Care. 2003;26(2):372-379.

101. Pfannenberg C, Werner MK, Ripkens S, et al. Impact of age on the relationships of brown adipose tissue with sex and adiposity in humans. Diabetes. 2010;59(7):1789-1793.

102. Gabaldon AM, McDonald RB, Horwitz BA. Effects of age, gender, and senescence on beta-adrenergic responses of isolated F344 rat brown adipocytes in vitro. Am J Physiol. 1998;274(4 Pt 1):E726-E736.

103. McDonald RB, Horwitz BA. Brown adipose tissue thermogenesis during aging and senescence. J Bioenerg Biomembr. 1999;31(5):507-516.

104. Cannon B, Nedergaard J. Brown adipose tissue: function and physiological significance. Physiol Rev. 2004;84(1):277-359.

105. Buyse M, Viengchareun S, Bado A, Lombes M. Insulin and glucocorticoids differentially regulate leptin transcription and secretion in brown adipocytes. FASEB J. 2001;15(8):1357-1366.

106. Ueno N, Oh-ishi S, Segawa M, et al. Effect of age on brown adipose tissue activity in the obese (ob/ob) mouse. Mech Ageing Dev. 1998 ; 100(1):67-76.

107. Kirkland JL, Tchkonia T, Pirtskhalava T, Han J, Karagiannides I. Adipogenesis and aging: does aging make fat go MAD? Exp Gerontol. 2002;37(6):757-767.

108. Hughes VA, Roubenoff R, Wood M, Frontera WR, Evans WJ, Fiatarone Singh MA. Anthropometric assessment of 10-y changes in body composition in the elderly. Am J Clin Nutr. 2004;80(2):475-482.

109. Van Harmelen V, Reynisdottir S, Eriksson P, et al. Leptin secretion from subcutaneous and visceral adipose tissue in women. Diabetes. 1998;47(6):913-917.

110. Eckel RH, Grundy SM, Zimmet PZ. The metabolic syndrome. Lancet. 2005;365(9468):1415-1428.

111. Van Harmelen V, Rohrig K, Hauner H. Comparison of proliferation and differentiation capacity of human adipocyte precursor cells from the omental and subcutaneous adipose tissue depot of obese subjects. Metabolism. 2004;53(5):632-637.

112. Arner P, Bernard S, Salehpour M, et al. Dynamics of human adipose lipid turnover in health and metabolic disease. Nature. 2011; 478(7367):110-113.

113. Karagiannides I, Thomou T, Tchkonia T, et al. Increased CUG triplet repeat-binding protein-1 predisposes to impaired adipogenesis with aging. J Biol Chem. 2006;281(32):23025-23033.

114. Spalding KL, Arner E, Westermark PO, et al. Dynamics of fat cell turnover in humans. Nature. 2008;453(7196):783-787.

115. Djian P, Roncari AK, Hollenberg CH. Influence of anatomic site and age on the replication and differentiation of rat adipocyte precursors in culture. J Clin Invest. 1983;72(4):1200-1208.

116. Kirkland JL, Hollenberg CH, Gillon WS. Age, anatomic site, and the replication and differentiation of adipocyte precursors. Am J Physiol. 1990;258(2 Pt 1):C206-C210.

117. Kirkland JL, Dax EM. Adipocyte hormone responsiveness and aging in the rat: problems in the interpretation of aging research. J Am Geriatr Soc. 1984;32(3):219-228.

118. Gregerman RI. Aging and hormone-sensitive lipolysis: reconciling the literature. J Gerontol. 1994;49(4):B135-B139.

119. Fried SK, Bunkin DA, Greenberg AS. Omental and subcutaneous adipose tissues of obese subjects release interleukin-6: depot difference and regulation by glucocorticoid. J Clin Endocrinol Metab. 1998; 83(3):847-850.

120. Ahren B, Mansson S, Gingerich RL, Havel PJ. Regulation of plasma leptin in mice: influence of age, high-fat diet, and fasting. Am J Physiol. 1997;273(1 Pt 2):R113-R120. 
121. Li H, Matheny M, Nicolson M, Tumer N, Scarpace PJ. Leptin gene expression increases with age independent of increasing adiposity in rats. Diabetes. 1997;46(12):2035-2039.

122. Wang FN, Ma CG, Zhang NX, Song HY. Glucose and Insulin Regulate Leptin Expression in 3T3-F442A Adipocytes. Sheng Wu Hua Xue Yu Sheng Wu Wu Li Xue Bao (Shanghai). 1999;31(3): 350-352.

123. Sanchez-Rodriguez M, Garcia-Sanchez A, Retana-Ugalde R, Mendoza-Nunez VM. Serum leptin levels and blood pressure in the overweight elderly. Arch Med Res. 2000;31(4):425-428.

124. Engineer DR, Garcia JM. Leptin in anorexia and cachexia syndrome. Int J Pept. 2012;2012:287457.

125. Scarpace PJ, Matheny M, Moore RL, Tumer N. Impaired leptin responsiveness in aged rats. Diabetes. 2000;49(3):431-435.

126. Gabriely I, Ma XH, Yang XM, Rossetti L, Barzilai N. Leptin resistance during aging is independent of fat mass. Diabetes. 2002;51(4): 1016-1021.

127. Mack I, BelAiba RS, Djordjevic T, Gorlach A, Hauner H, Bader BL. Functional analyses reveal the greater potency of preadipocytes compared with adipocytes as endothelial cell activator under normoxia, hypoxia, and TNFalpha exposure. Am J Physiol Endocrinol Metab. 2009;297(3):E735-E748.

128. Chung S, Lapoint K, Martinez K, Kennedy A, Boysen Sandberg M, McIntosh MK. Preadipocytes mediate lipopolysaccharide-induced inflammation and insulin resistance in primary cultures of newly differentiated human adipocytes. Endocrinology. 2006;147(11): 5340-5351.

129. Harkins JM, Moustaid-Moussa N, Chung YJ, et al. Expression of interleukin-6 is greater in preadipocytes than in adipocytes of 3T3-L1 cells and C57BL/6J and ob/ob mice. J Nutr. 2004;134(10):2673-2677.

130. Cousin B, Munoz O, Andre M, et al. A role for preadipocytes as macrophage-like cells. FASEB J. 1999;13(2):305-312.

131. Weisberg SP, McCann D, Desai M, Rosenbaum M, Leibel RL, Ferrante AW Jr. Obesity is associated with macrophage accumulation in adipose tissue. J Clin Invest. 2003;112(12):1796-1808.

132. Sevastianova K, Sutinen J, Kannisto K, Hamsten A, Ristola M, Yki-Jarvinen H. Adipose tissue inflammation and liver fat in patients with highly active antiretroviral therapy-associated lipodystrophy. Am J Physiol Endocrinol Metab. 2008;295(1):E85-E91.

133. Lumeng CN, Bodzin JL, Saltiel AR. Obesity induces a phenotypic switch in adipose tissue macrophage polarization. J Clin Invest. 2007; 117(1):175-184.

134. Miard S, Picard F. Obesity and aging have divergent genomic fingerprints. Int J Obes (Lond). 2008;32(12):1873-1874.

135. Miard S, Dombrowski L, Carter S, Boivin L, Picard F. Aging alters PPARgamma in rodent and human adipose tissue by modulating the balance in steroid receptor coactivator-1. Aging Cell. 2009;8(4):449-459.

136. Arai Y, Takayama M, Gondo Y, et al. Adipose endocrine function, insulinlike growth factor-1 axis, and exceptional survival beyond 100 years of age. J Gerontol A Biol Sci Med Sci. 2008;63(11):1209-1218.

137. Arai Y, Takayama M, Abe Y, Hirose N. Adipokines and aging. J Atheroscler Thromb. 2011;18(7):545-550.

138. Harvey PH, Zammuto RM. Patterns of mortality and age at first reproduction in natural populations of mammals. Nature. 1985; 315(6017):319-320.

139. Merry BJ, Holehan AM. Onset of puberty and duration of fertility in rats fed a restricted diet. J Reprod Fertil. 1979;57(2):253-259.

140. Brown-Borg HM. Hormonal control of aging in rodents: the somatotropic axis. Mol Cell Endocrinol. 2009;299(1):64-71.

141. Yuan R, Meng Q, Nautiyal J, et al. Genetic coregulation of age of female sexual maturation and lifespan through circulating IGF1 among inbred mouse strains. Proc Natl Acad Sci U S A. 2012;109(21):8224-8229.

142. Ukkola O, Santaniemi M. Adiponectin: a link between excess adiposity and associated comorbidities? J Mol Med (Berl). 2002;80(11):696-702.

143. Atzmon G, Pollin TI, Crandall J, et al. Adiponectin levels and genotype: a potential regulator of life span in humans. $J$ Gerontol A Biol Sci Med Sci. 2008;63(5):447-453.
144. Bik W, Baranowska-Bik A, Wolinska-Witort E, et al. The relationship between adiponectin levels and metabolic status in centenarian, early elderly, young and obese women. Neuro Endocrinol Lett. 2006; 27(4):493-500.

145. Franceschi C, Monti D, Sansoni P, Cossarizza A. The immunology of exceptional individuals: the lesson of centenarians. Immunol Today. 1995;16(1):12-16.

146. Hitt R, Young-Xu Y, Silver M, Perls T. Centenarians: the older you get, the healthier you have been. Lancet. 1999;354(9179):652.

147. Arai Y, Kojima T, Takayama M, Hirose N. The metabolic syndrome, IGF-1, and insulin action. Mol Cell Endocrinol. 2009;299(1):124-128.

148. Ford ES, Giles WH, Dietz WH. Prevalence of the metabolic syndrome among US adults: findings from the third National Health and Nutrition Examination Survey. JAMA. 2002;287(3):356-359.

149. Paolisso G, Gambardella A, Ammendola S, et al. Glucose tolerance and insulin action in healty centenarians. Am J Physiol. 1996; 270(5 Pt 1):E890-E894.

150. Paolisso G, Gambardella A, Balbi V, Ammendola S, D'Amore A, Varricchio M. Body composition, body fat distribution, and resting metabolic rate in healthy centenarians. Am J Clin Nutr. 1995;62(4): 746-750.

151. Bluher M, Kahn BB, Kahn CR. Extended longevity in mice lacking the insulin receptor in adipose tissue. Science. 2003; 299(5606):572-574.

152. Mehta LH, Roth GS. Caloric restriction and longevity: the science and the ascetic experience. Ann N Y Acad Sci. 2009;1172:28-33.

153. Barzilai N, Gupta G. Revisiting the role of fat mass in the life extension induced by caloric restriction. J Gerontol A Biol Sci Med Sci. 1999;54(3):B89-B96; discussion B97-B88.

154. Gabriely I, Barzilai N. Surgical removal of visceral adipose tissue: effects on insulin action. Curr Diab Rep. 2003;3(3):201-206.

155. Muzumdar R, Allison DB, Huffman DM, et al. Visceral adipose tissue modulates mammalian longevity. Aging Cell. 2008;7(3):438-440.

156. Chiu CH, Lin WD, Huang SY, Lee YH. Effect of a C/EBP gene replacement on mitochondrial biogenesis in fat cells. Genes Dev. 2004;18(16):1970-1975.

157. Fogteloo AJ, Pij1 H, Frolich M, McCamish M, Meinders AE. Effects of recombinant human leptin treatment as an adjunct of moderate energy restriction on body weight, resting energy expenditure and energy intake in obese humans. Diabetes Nutr Metab. 2003;16(2): 109-114.

158. McDuffie JR, Riggs PA, Calis KA, et al. Effects of exogenous leptin on satiety and satiation in patients with lipodystrophy and leptin insufficiency. J Clin Endocrinol Metab. 2004;89(9):4258-4263.

159. Oral EA, Simha V, Ruiz E, et al. Leptin-replacement therapy for lipodystrophy. N Engl J Med. 2002;346(8):570-578.

160. Scarpace PJ, Zhang Y. Leptin resistance: a prediposing factor for diet-induced obesity. Am J Physiol. 2009;296(3):R493-R500.

161. Myers MG Jr, Heymsfield SB, Haft C, et al. Challenges and opportunities of defining clinical leptin resistance. Cell Metab. 2012; 15(2):150-156.

162. Enriori PJ, Evans AE, Sinnayah P, et al. Diet-induced obesity causes severe but reversible leptin resistance in arcuate melanocortin neurons. Cell Metab. 2007;5(3):181-194.

163. Munzberg H, Myers MG Jr. Molecular and anatomical determinants of central leptin resistance. Nat Neurosci. 2005;8(5):566-570.

164. Banks WA. The many lives of leptin. Peptides. Mar 2004;25(3): 331-338.

165. Fry M, Ferguson AV. The sensory circumventricular organs: brain targets for circulating signals controlling ingestive behavior. Physiol Behav. 2007;91(4):413-423.

166. Levin BE, Dunn-Meynell AA, Banks WA. Obesity-prone rats have normal blood-brain barrier transport but defective central leptin signaling before obesity onset. Am J Physiol. 2004;286(1):R143-R150.

167. Muzumdar RH, Ma X, Yang X, Atzmon G, Barzilai N. Central resistance to the inhibitory effects of leptin on stimulated insulin secretion with aging. Neurobiol Aging. 2006;27(9):1308-1314. 
168. Schwartz MW, Peskind E, Raskind M, Boyko EJ, Porte D Jr. Cerebrospinal fluid leptin levels: relationship to plasma levels and to adiposity in humans. Nat Med. 1996;2(5):589-593.

169. Banks WA, Coon AB, Robinson SM, et al. Triglycerides induce leptin resistance at the blood-brain barrier. Diabetes. 2004;53(5): $1253-1260$.

170. Fernandez-Galaz C, Fernandez-Agullo T, Campoy F, et al. Decreased leptin uptake in hypothalamic nuclei with ageing in Wistar rats. J Endocrinol. 2001;171(1):23-32.

171. Gruenewald DA, Matsumoto AM. Age-related decrease in proopiomelanocortin gene expression in the arcuate nucleus of the male rat brain. Neurobiol Aging. 1991;12(2):113-121.

172. Scarpace PJ, Matheny M, Tumer N. Hypothalamic leptin resistance is associated with impaired leptin signal transduction in aged obese rats. Neuroscience. 2001;104(4):1111-1117.

173. Shek EW, Scarpace PJ. Resistance to the anorexic and thermogenic effects of centrally administrated leptin in obese aged rats. Regul Pept. 2000;92(1-3):65-71.

174. Qiu J, Ogus S, Lu R, Chehab FF. Transgenic mice overexpressing leptin accumulate adipose mass at an older, but not younger, age. Endocrinology. 2001;142(1):348-358.

175. Heymsfield SB, Greenberg AS, Fujioka K, et al. Recombinant leptin for weight loss in obese and lean adults: a randomized, controlled, dose-escalation trial. JAMA. 1999;282(16):1568-1575.

176. Mittendorfer B, Horowitz JF, DePaoli AM, McCamish MA, Patterson BW, Klein S. Recombinant human leptin treatment does not improve insulin action in obese subjects with type 2 diabetes. Diabetes. 2011;60(5):1474-1477.

177. Wyse BM, Dulin WE. The influence of age and dietary conditions on diabetes in the db mouse. Diabetologia. 1970;6(3):268-273.

178. Aasum E, Hafstad AD, Severson DL, Larsen TS. Age-dependent changes in metabolism, contractile function, and ischemic sensitivity in hearts from db/db mice. Diabetes. 2003;52(2):434-441.

179. Senador D, Kanakamedala K, Irigoyen MC, Morris M, Elased KM. Cardiovascular and autonomic phenotype of $\mathrm{db} / \mathrm{db}$ diabetic mice. Exper Physiol. 2009;94(6):648-658.

180. Kodama H, Fujita M, Yamaguchi I. Development of hyperglycaemia and insulin resistance in conscious genetically diabetic (C57BL/ KsJ-db/db) mice. Diabetologia. 1994;37(8):739-744.

181. Folch J, Pedros I, Patraca I, et al. Neuroprotective and anti-ageing role of leptin. J Mol Endocrinol. 2012;49(3):R149-R156.

182. Naderali EK, Ratcliffe SH, Dale MC. Obesity and Alzheimer's disease: a link between body weight and cognitive function in old age. Am J Alzheimers Dis Other Demen. 2009;24(6):445-449.

183. Tezapsidis N, Johnston JM, Smith MA, et al. Leptin: a novel therapeutic strategy for Alzheimer's disease. J Alzheimers Dis. 2009;16(4):731-740.

184. Lieb W, Beiser AS, Vasan RS, et al. Association of plasma leptin levels with incident Alzheimer disease and MRI measures of brain aging. JAMA. 2009;302(23):2565-2572.

185. Holden KF, Lindquist K, Tylavsky FA, Rosano C, Harris TB, Yaffe K. Serum leptin level and cognition in the elderly: Findings from the Health ABC Study. Neurobiol Aging. 2009;30(9):1483-1489.

186. Li XL, Aou S, Oomura Y, Hori N, Fukunaga K, Hori T. Impairment of long-term potentiation and spatial memory in leptin receptor-deficient rodents. Neuroscience. 2002;113(3):607-615.

187. Singh-Manoux A, Czernichow S, Elbaz A, et al. Obesity phenotypes in midlife and cognition in early old age: the Whitehall II cohort study. Neurology. 2012;79(8):755-762.

188. Sell H, Deshaies Y, Richard D. The brown adipocyte: update on its metabolic role. Int J Biochem Cell Biol. 2004;36(11): 2098-2104.

189. Richard D, Carpentier AC, Dore G, Ouellet V, Picard F. Determinants of brown adipocyte development and thermogenesis. Int J Obes (Lond) 2010;34 Suppl 2:S59-S66.

190. Richard D, Picard F. Brown fat biology and thermogenesis. Front Biosci. 2011;16:1233-1260.
191. Lean ME. Brown adipose tissue in humans. Proc Nutr Soc. 1989; 48(2):243-256.

192. Heaton JM. The distribution of brown adipose tissue in the human. J Anat. 1972;112(Pt 1):35-39.

193. Zingaretti MC, Crosta F, Vitali A, et al. The presence of UCP1 demonstrates that metabolically active adipose tissue in the neck of adult humans truly represents brown adipose tissue. FASEB J. 2009; 23(9):3113-3120.

194. Cypess AM, Lehman S, Williams G, et al. Identification and importance of brown adipose tissue in adult humans. $N$ Engl J Med. 2009;360(15):1509-1517.

195. Richard D, Monge-Roffarello B, Chechi K, Labbe SM, Turcotte EE. Control and physiological determinants of sympathetically mediated brown adipose tissue thermogenesis. Front Endocrinol. 2012;3:36.

196. Ouellet V, Routhier-Labadie A, Bellemare W, et al. Outdoor temperature, age, sex, body mass index, and diabetic status determine the prevalence, mass, and glucose-uptake activity of 18F-FDG-detected BAT in humans. J Clin Endocrinol Metab. 2011;96(1):192-199.

197. Lee P, Greenfield JR, Ho KK, Fulham MJ. A critical appraisal of the prevalence and metabolic significance of brown adipose tissue in adult humans. Am J Physiol Endocrinol Metab. 2010;299(4): E601-E606.

198. Drubach LA, Palmer EL 3rd, Connolly LP, Baker A, Zurakowski D, Cypess AM. Pediatric brown adipose tissue: detection, epidemiology, and differences from adults. J Pediatr. 2011;159(6):939-944.

199. Tam CS, Lecoultre V, Ravussin E. Brown adipose tissue: mechanisms and potential therapeutic targets. Circulation. 2012;125(22): 2782-2791.

200. Saely CH, Geiger K, Drexel H. Brown versus white adipose tissue: a mini-review. Gerontology. 2012;58(1):15-23.

201. Himms-Hagen J, Desautels M. A mitochondrial defect in brown adipose tissue of the obese (ob/ob) mouse: reduced binding of purine nucleotides and a failure to respond to cold by an increase in binding. Biochem Biophys Res Comm. 1978;83(2):628-634.

202. Bartness TJ, Vaughan CH, Song CK. Sympathetic and sensory innervation of brown adipose tissue. Int J Obes (Lond). 2010; 34 Suppl 1:S36-S42.

203. Langin D, Tavernier G, Lafontan M. Regulation of beta 3-adrenoceptor expression in white fat cells. Fundam Clin Pharmacol. 1995;9(2) 97-106.

204. Scarpace PJ, Tse C, Matheny M. Thermoregulation with age: restoration of beta(3)-adrenergic responsiveness in brown adipose tissue by cold exposure. Proc Soc Exp Biol Med. 1996;211(4):374-380.

205. Seals DR, Esler MD. Human ageing and the sympathoadrenal system. J Physiol. 2000;528(Pt 3):407-417.

206. Morrison SF, Madden CJ, Tupone D. Central control of brown adipose tissue thermogenesis. Front Endocrinol. 2012;3(5).

207. Dunbar JC, Lu H. Leptin-induced increase in sympathetic nervous and cardiovascular tone is mediated by proopiomelanocortin (POMC) products. Brain Res Bull. 1999;50(3):215-221.

208. Levine AS, Morley JE. Neuropeptide Y: a potent inducer of consummatory behavior in rats. Peptides. 1984;5(6):1025-1029

209. Billington CJ, Briggs JE, Grace M, Levine AS. Effects of intracerebroventricular injection of neuropeptide $\mathrm{Y}$ on energy metabolism. Am J Physiol. 1991;260(2 Pt 2):R321-R327.

210. Zhang Y, Kilroy GE, Henagan TM, et al. Targeted deletion of melanocortin receptor subtypes 3 and 4, but not CART, alters nutrient partitioning and compromises behavioral and metabolic responses to leptin. FASEB J. 2005;19(11):1482-1491.

211. Mattson MP. Perspective: Does brown fat protect against diseases of aging? Ageing Res Rev. 2010;9(1):69-76.

212. Valle A, Guevara R, Garcia-Palmer FJ, Roca P, Oliver J. Caloric restriction retards the age-related decline in mitochondrial function of brown adipose tissue. Rejuv Res. 2008;11(3):597-604.

213. Silvestri E, Schiavo L, Lombardi A, Goglia F. Thyroid hormones as molecular determinants of thermogenesis. Acta Physiol Scand. 2005; 184(4):265-283 


\section{Publish your work in this journal}

Clinical Interventions in Aging is an international, peer-reviewed journal focusing on evidence-based reports on the value or lack thereof of treatments intended to prevent or delay the onset of maladaptive correlates of aging in human beings. This journal is indexed on PubMed Central, MedLine, the American Chemical Society's 'Chemical Abstracts

Service' (CAS), Scopus and the Elsevier Bibliographic databases. The manuscript management system is completely online and includes a very quick and fair peer-review system, which is all easy to use. Visit $\mathrm{http} / / / \mathrm{www}$.dovepress.com/testimonials.php to read real quotes from published authors.

Submit your manuscript here: http://www.dovepress.com/clinical-interventions-in-aging-journal 